\title{
Naphthacemycins, novel circumventors of $\beta$-lactam resistance in MRSA, produced by Streptomyces sp. KB-3346-5. I. The taxonomy of the producing strain, and the fermentation, isolation and antibacterial activities
}

\author{
Atsushi Fukumoto ${ }^{1,6}$, Yong-Pil Kim ${ }^{2,7}$, Atsuko Matsumoto ${ }^{2}$, Yoko Takahashi ${ }^{1,2}$, Makoto Suzuki ${ }^{3}$, \\ Hideyuki Onodera $^{4}$, Hiroshi Tomoda ${ }^{5}$, Hidehito Matsui ${ }^{2}$, Hideaki Hanaki ${ }^{2}$, Masato Iwatsuki ${ }^{1,2}$, \\ Satoshi Ōmura ${ }^{2}$ and Kazuro Shiomi ${ }^{1,2}$
}

Screening for circumventors of $\beta$-lactam resistance in methicillin-resistant Staphylococcus aureus (MRSA) led us to find 17 novel antibiotics, naphthacemycins $A_{1}-A_{11}, B_{1}-B_{4}$ and $C_{1}-C_{2}$. The naphthacemycins were isolated from a cultured broth of Streptomyces sp. KB-3346-5 by repeated silica gel column chromatography and HPLC. Naphthacemycins enhanced imipenem activity $100-500$ times against MRSA at $0.5 \mu \mathrm{g} \mathrm{ml}-1$, and naphthacemycins $A_{4}-A_{11}$ themselves showed MIC ${ }_{50}$ values of $1-4 \mu \mathrm{g} \mathrm{ml}^{-1}$ against 22 MRSA strains.

The Journal of Antibiotics (2017) 70, 562-567; doi:10.1038/ja.2017.28; published online 15 March 2017

\section{INTRODUCTION}

Methicillin-resistant Staphylococcus aureus (MRSA) is a causative microorganism of opportunistic infection that harms individuals in medical facilities who have compromised immune systems. Recently, it has also been gaining in significance as a cause of serious community-acquired infections among healthy people. ${ }^{1}$ Although there are a few antibiotics used to combat MRSA (for example, vancomycin, teicoplanin, arbekacin, linezolid, daptomycin, tigecycline, ceftaroline, dalbavancin, oritavancin and tedizolid) microorganisms with resistance to some of them are increasingly being reported. In the course of screening for new antibiotics active against MRSA, we have recently found biverlactones, which are capable of circumventing arbekacin resistance in MRSA. They are thought to inhibit aminoglycoside-modifying enzymes. ${ }^{2}$ We have also reported that cyslabdan enhances imipenem activity against MRSA.,4 Our continuous study to find microbial metabolites, like cyslabdan, that circumvent $\beta$-lactam resistance of MRSA, led us to discover further novel compounds, the naphthacemycins $\mathrm{A}_{1}-\mathrm{A}_{11}$ (1-11), $\mathrm{B}_{1}-\mathrm{B}_{4}$ (12-15) and $\mathrm{C}_{1}-\mathrm{C}_{2}$ (16-17) (Figure 1), reported as KB-3346-5 substances in the patent by our group ${ }^{5}$, isolated from a culture broth of Streptomyces sp. KB-3346-5. In this report, we describe the taxonomy of the producing strain, as well as the fermentation, isolation and antibacterial activities of these naphthacemycin compounds.

\section{RESULTS AND DISCUSSION}

Taxonomy of the producing organism

Strain KB-3346-5 was originally isolated from a soil sample collected in Okinawa Prefecture, Japan. The vegetative mycelia developed well on yeast extract-malt extract agar and nutrient agar, and the color was brown. The aerial mycelia were produced abundantly on yeast extract-malt extract agar, and the aerial mass color showed white to yellow. The mature spore chains were spiral and each had more than 20 spores per chain. The spores were cylindrical in shape, $0.5-0.6 \times 0.7-0.8 \mathrm{~mm}$ in size and had a smooth surface (Figure 2). The isomer of diaminopimelic acid in whole-cell hydrolysates was LL-form. Major menaquinones were MK-9 ( $\left.\mathrm{H}_{6}\right)$ and MK-9 $\left(\mathrm{H}_{8}\right)$. Based on the taxonomic properties above, the microorganism was considered to belong to the genus Streptomyces ${ }^{6}$ and was named Streptomyces sp. KB-3346-5. The strain was deposited at the

${ }^{1}$ Graduate School of Infection Control Sciences, Kitasato University, Tokyo, Japan; ${ }^{2}$ Kitasato Institute for Life Sciences, Kitasato University, Tokyo, Japan; ${ }^{3}$ Healthcare Products Development Center, Kyowa Hakko Bio Co., Ltd, Ibaraki, Japan; ${ }^{4}$ Chemical Research Laboratories, Kyowa Hakko Kirin Co., Ltd, Shizuoka, Japan and ${ }^{5}$ School of Pharmacy, Kitasato University, Tokyo, Japan

${ }^{6}$ Current address: Faculty of Pharmaceutical Sciences, Toho University, Funabashi, Chiba, Japan.

${ }^{7}$ Current address: Faculty of Pharmacy, Iwaki Meisei University, Iwaki, Fukushima, Japan.

Correspondence: Professor S Ōmura or Professor K Shiomi, Kitasato Institute for Life Sciences, Kitasato University, 5-9-1 Shirokane, Minato-ku, Tokyo 108-8641, Japan.

E-mail: omuras@insti.kitasato-u.ac.jp or shiomi@lisci.kitasato-u.ac.jp

Received 24 October 2016; revised 23 January 2017; accepted 1 February 2017; published online 15 March 2017 


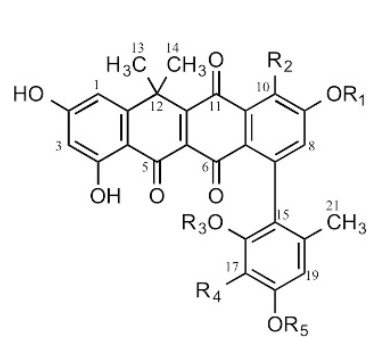

Naphthacemycin A series

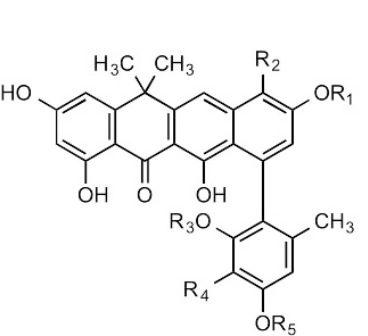

Naphthacemycin B series

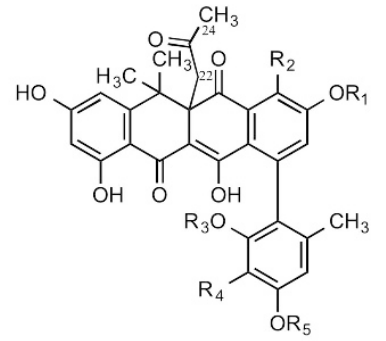

Naphthacemycin C series
Naphthacemycin $A_{1}(\mathbf{1})$

Naphthacemycin $\mathrm{A}_{2}$ (2)

Naphthacemycin $\mathrm{A}_{3}(\mathbf{3})$

Naphthacemycin $\mathrm{A}_{4}$ (4)

Naphthacemycin $A_{5}(\mathbf{5})$

Naphthacemycin $\mathrm{A}_{6}(\mathbf{6})$

Naphthacemycin $A_{7}$ (7)

Naphthacemycin $A_{8}(8)$

Naphthacemycin $A_{9}(\mathbf{9})$

Naphthacemycin $A_{10}(\mathbf{1 0})$

Naphthacemycin $\mathrm{A}_{11}$ (11)

Naphthacemycin $B_{1}$ (12)

Naphthacemycin $B_{2}(\mathbf{1 3})$

Naphthacemycin $B_{3}(\mathbf{1 4})$

Naphthacemycin $B_{4}(\mathbf{1 5})$

Naphthacemycin $C_{1}(\mathbf{1 6})$

Naphthacemycin $C_{2}(17)$

$\begin{array}{ccccc}\mathrm{R}_{1} & \mathrm{R}_{2} & \mathrm{R}_{3} & \mathrm{R}_{4} & \mathrm{R}_{5} \\ \mathrm{H} & \mathrm{H} & \mathrm{CH}_{3} & \mathrm{H} & \mathrm{H} \\ \mathrm{H} & \mathrm{H} & \mathrm{CH}_{3} & \mathrm{Cl} & \mathrm{H} \\ \mathrm{CH}_{3} & \mathrm{H} & \mathrm{CH}_{3} & \mathrm{H} & \mathrm{H} \\ \mathrm{CH}_{3} & \mathrm{Cl} & \mathrm{CH}_{3} & \mathrm{H} & \mathrm{H} \\ \mathrm{H} & \mathrm{H} & \mathrm{CH}_{3} & \mathrm{Cl} & \mathrm{CH}_{3} \\ \mathrm{CH}_{3} & \mathrm{H} & \mathrm{CH}_{3} & \mathrm{Cl} & \mathrm{H} \\ \mathrm{CH}_{3} & \mathrm{Cl} & \mathrm{CH}_{3} & \mathrm{Cl} & \mathrm{H} \\ \mathrm{CH}_{3} & \mathrm{Cl} & \mathrm{CH}_{3} & \mathrm{H} & \mathrm{CH}_{3} \\ \mathrm{CH}_{3} & \mathrm{H} & \mathrm{CH}_{3} & \mathrm{H} & \mathrm{CH}_{3} \\ \mathrm{CH}_{3} & \mathrm{Cl} & \mathrm{CH}_{3} & \mathrm{Cl} & \mathrm{CH}_{3} \\ \mathrm{CH}_{3} & \mathrm{H} & \mathrm{CH}_{3} & \mathrm{Cl} & \mathrm{CH}_{3} \\ \mathrm{H} & \mathrm{H} & \mathrm{H}^{2} & \mathrm{H} & \mathrm{H} \\ \mathrm{H} & \mathrm{H} & \mathrm{CH}_{3} & \mathrm{H} & \mathrm{H} \\ \mathrm{H} & \mathrm{H} & \mathrm{CH}_{3} & \mathrm{Cl} & \mathrm{H} \\ \mathrm{H} & \mathrm{Cl} & \mathrm{CH}_{3} & \mathrm{H} & \mathrm{H} \\ \mathrm{CH}_{3} & \mathrm{Cl} & \mathrm{CH}_{3} & \mathrm{H} & \mathrm{H} \\ \mathrm{CH}_{3} & \mathrm{H} & \mathrm{CH}_{3} & \mathrm{Cl} & \mathrm{CH}_{3}\end{array}$

Figure 1 Structures of naphthacemycins $A_{1}-A_{11}$ (1-11), $B_{1}-B_{4}$ (12-15) and $C_{1}-C_{2}$ (16-17).

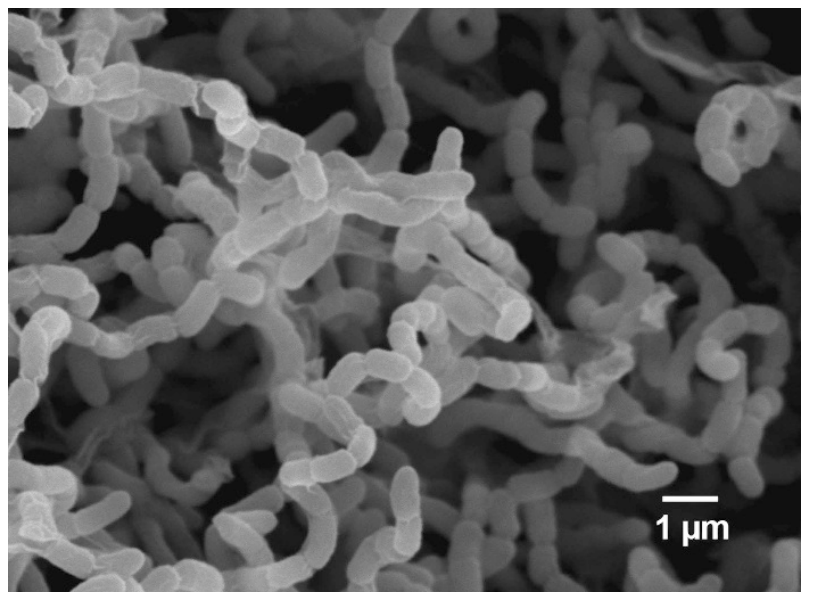

Figure 2 Scanning electron micrograph of the strain KB-3346-5 grown on yeast extract-malt extract agar at $27^{\circ} \mathrm{C}$ for 2 weeks.

International Patent Organism Depositary, National Institute of Advanced Industrial Science and Technology, Tsukuba, Japan, as FERM BP-10834.

\section{Fermentation and isolation}

A loop of cells of strain KB-3346-5 on the agar slant was inoculated into each of five test tubes containing $10 \mathrm{ml}$ of a seed medium and shaken at $27^{\circ} \mathrm{C}$ for 3 days. The seed broth $(10 \mathrm{ml})$ was inoculated into each of five $500-\mathrm{ml}$ Erlenmeyer flasks containing $100 \mathrm{ml}$ of the seed medium and incubated on a rotary shaker at $27^{\circ} \mathrm{C}$ for 3 days. The second seed broth $(10 \mathrm{ml})$ was inoculated into each of fifty $500-\mathrm{ml}$
Erlenmeyer flasks containing $100 \mathrm{ml}$ of a production medium, and the fermentation was carried out on a rotary shaker at $28^{\circ} \mathrm{C}$ for 8 days. The production of naphthacemycins began at 3-4 days and reached nearly maximum at 6 days (data not shown).

The cultured broth was extracted with acetone, and the extract was further extracted with ethyl acetate. The ethyl acetate extract was purified by silica gel column chromatography twice and HPLC to yield naphthacemycins $A_{1}-A_{11}$ (1-11), $B_{1}-B_{4}(12-15)$ and $C_{1}-C_{2}(16-17)$. Their structures were elucidated by NMR experiments and X-ray analysis, as reported elsewhere. ${ }^{7}$ Naphthacemycins displayed unique skeletons as natural products, consisting of a naphthacene ring monosubstituted with a phenyl residue at C-7 (Figure 1).

\section{Biological activities}

The circumvention of $\beta$-lactam resistance in MRSA was measured by enhancement of imipenem activity against MRSA. Naphthacemycins alone showed MIC values of $8-64 \mu \mathrm{g} \mathrm{ml}^{-1}$ against clinically isolated MRSA strain K24. In the presence of each $0.5 \mu \mathrm{g} \mathrm{ml}^{-1}$ of naphthacemycins, the MIC of imipenem was evaluated by the liquid dilution method. Without naphthacemycins, the MIC of imipenem was $32 \mu \mathrm{g} \mathrm{ml}^{-1}$. As shown in Table 1, addition of naphthacemycins reduced the MIC of imipenem to between 0.06 and $0.25 \mu \mathrm{g} \mathrm{ml}^{-1}$, yielding 128-512 times enhancement of imipenem activity. Among naphthacemycins, 3, 6, 7 and 13-15 showed 512 times enhancement.

The circumvention activity was further evaluated by a larger panel of staphylococci for sensitivity testing of imipenem activity using 22 clinically isolated MRSA and five MSSA (methicillin-sensitive S. aureus) strains. Concentrations of naphthacemycins, of $0.2 \mu \mathrm{g} \mathrm{ml}-1$ (for compounds 4-11) and $1 \mu \mathrm{g} \mathrm{ml}^{-1}$ (for compounds 1-3 and 12-17), did not inhibit the growth of tested bacteria. The ranges of 
Table 1 Anti-MRSA activity of imipenem enhanced by naphthacemycins

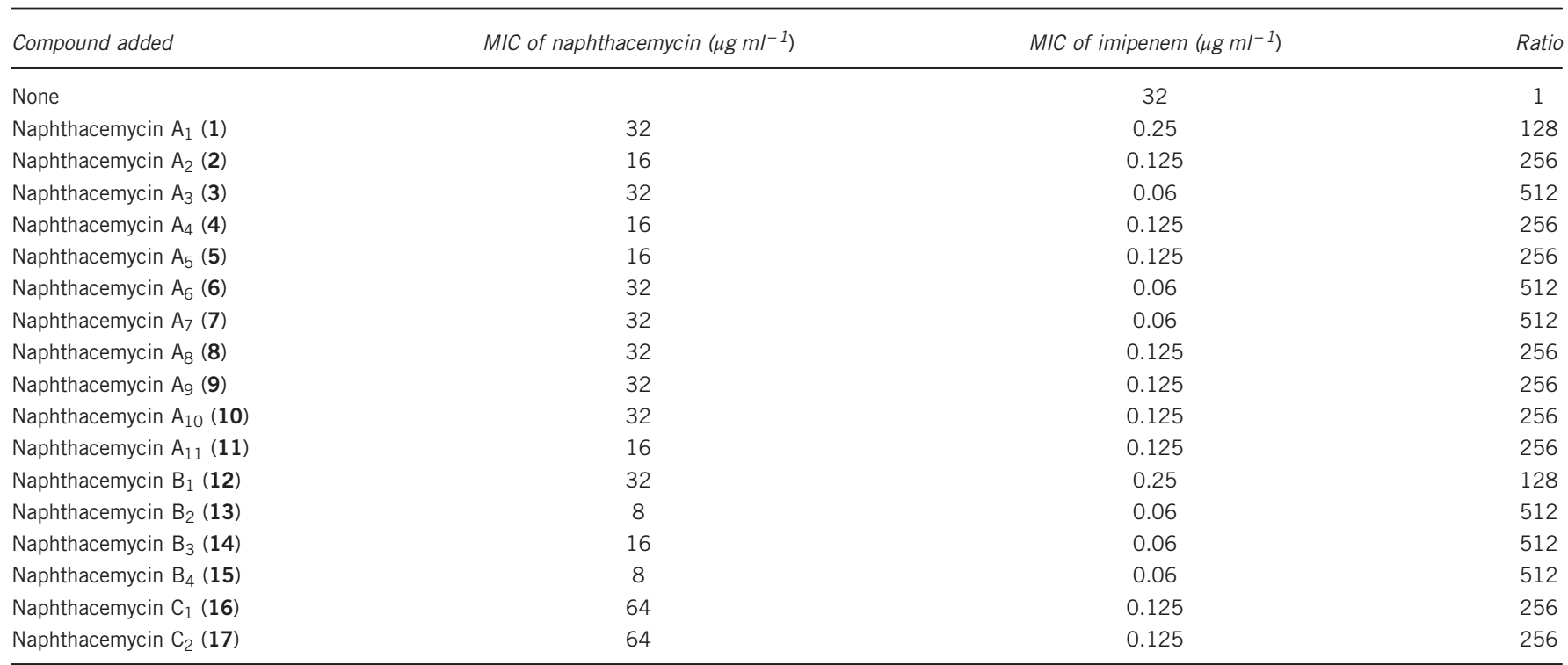

The concentration of each naphthacemycin was $0.5 \mu \mathrm{g} \mathrm{ml^{-1 }}$.

Table 2 MIC population of imipenem against MRSA and MSSA strains in the presence of naphthacemycins

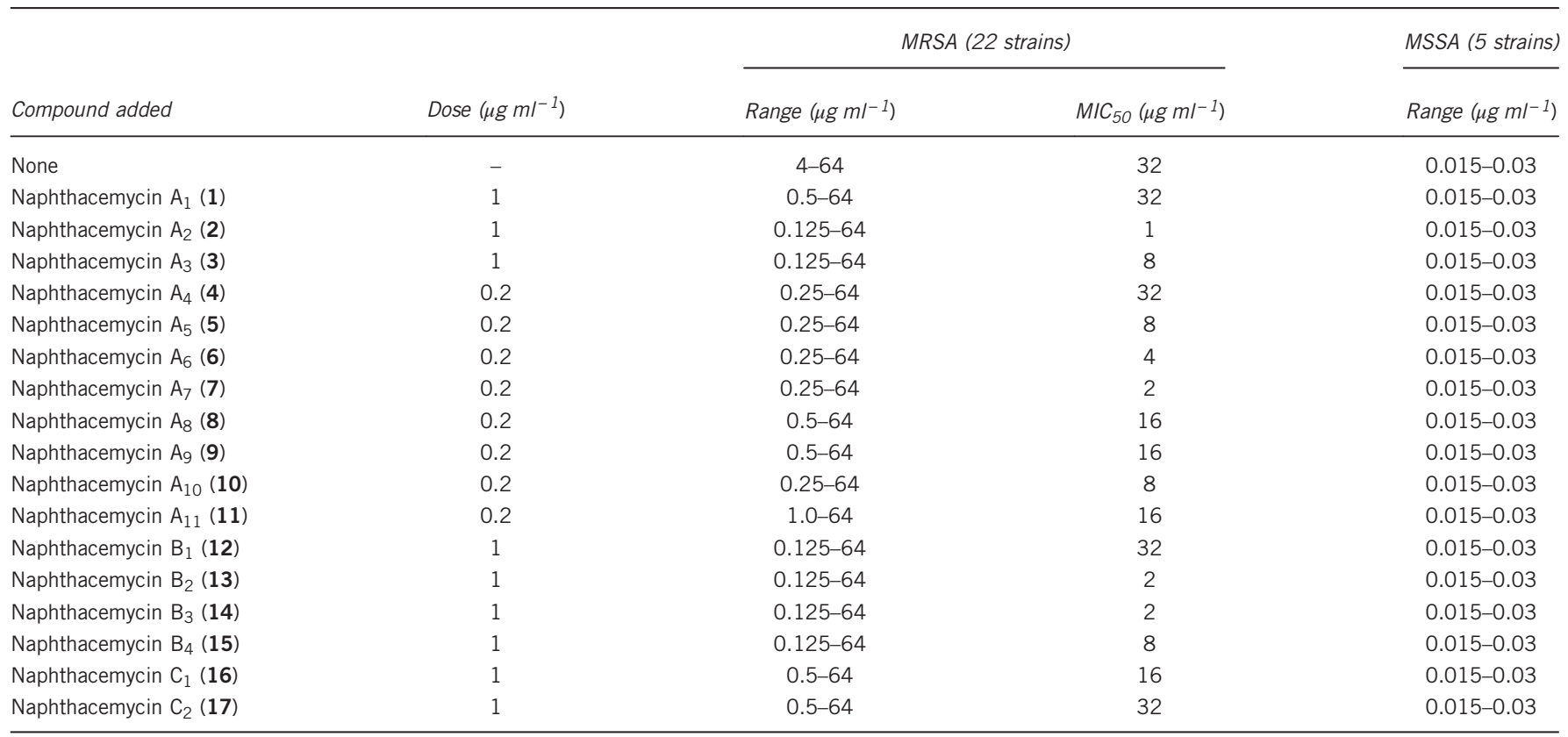

MIC values and the values of MIC $_{50}$ of the MRSA and MSSA strains are shown in Table 2. Most naphthacemycins reduced $\mathrm{MIC}_{50}$ values of imipenem and 2 reduced the value 32 -fold. However, naphthacemycins had no effect on imipenem activity against MSSA strains.

Thus, naphthacemycins circumvent imipenem resistance in MRSA, similar to cyslabdan, which we have reported previously, ${ }^{4}$ but the enhancement ratio of cyslabdan, was much higher (128 times at population analysis) than with the naphthacemycins. It is interesting that naphthacemycins enhanced imipenem activity at the concentration lower than that of cyslabdan, although the enhancement ratio was lower than cyslabdan. Therefore, antibacterial activity of naphthacemycins alone against MRSA and MSSA strains were evaluated by a larger panel of staphylococci for sensitivity testing (Table 3). Naphthacemycins other than 1, 12, 16 and 17 showed equal antibacterial activity against both MRSA and MSSA strains, and the $\mathrm{MIC}_{50}$ of $\mathbf{1 1}$ was $1 \mu \mathrm{g} \mathrm{ml}^{-1}$ and that of 5-8 and $\mathbf{1 0}$ was $2 \mu \mathrm{g} \mathrm{ml}^{-1}$, comparable to vancomycin.

The antibacterial activity of $\mathbf{8}$ and $\mathbf{9}$ (which were available in suitable quantities) against various $S$. aureus and a range of other bacteria was evaluated (Table 4). Compounds 8 and $\mathbf{9}$ showed antibacterial activity against Gram-positive bacteria. Their anti-MRSA activity was comparable to vancomycin, and they also inhibited the growth of 
Table 3 MIC population of naphthacemycins against MRSA and MSSA strains

\begin{tabular}{|c|c|c|c|}
\hline \multirow[b]{2}{*}{ Compound } & \multicolumn{2}{|c|}{ MRSA (22 strains) } & \multirow{2}{*}{$\begin{array}{l}\text { MSSA (5 strains) } \\
\text { Range ( } \mu \mathrm{g} \mathrm{ml}^{-1} \text { ) }\end{array}$} \\
\hline & Range $\left(\mu g \mathrm{ml}^{-1}\right.$ ) & $M I C_{50}\left(\mu g m I^{-1}\right)$ & \\
\hline Naphthacemycin $A_{1}(\mathbf{1})$ & $>8$ & $>8$ & $>8$ \\
\hline Naphthacemycin $A_{2}$ (2) & 8 & 8 & 8 \\
\hline Naphthacemycin $A_{3}$ (3) & $4-8$ & 8 & 4 \\
\hline Naphthacemycin $A_{4}$ (4) & $2-8$ & 4 & 4 \\
\hline Naphthacemycin $A_{5}(5)$ & $1-2$ & 2 & 2 \\
\hline Naphthacemycin $A_{6}(6)$ & $2-4$ & 2 & $1-2$ \\
\hline Naphthacemycin $A_{7}$ (7) & $1-4$ & 2 & 2 \\
\hline Naphthacemycin $A_{8}$ (8) & $0.5-4$ & 2 & 2 \\
\hline Naphthacemycin $A_{9}$ (9) & $2-4$ & 4 & $2-4$ \\
\hline Naphthacemycin $A_{10}(10)$ & $1-2$ & 2 & $1-2$ \\
\hline Naphthacemycin $A_{11}$ (11) & $0.5-2$ & 1 & 1 \\
\hline Naphthacemycin $B_{1}(\mathbf{1 2})$ & $>8$ & $>8$ & $>8$ \\
\hline Naphthacemycin $B_{2}$ (13) & 8 & 8 & 8 \\
\hline Naphthacemycin $B_{3}$ (14) & $4-8$ & 8 & $4-8$ \\
\hline Naphthacemycin $B_{4}(15)$ & $4-8$ & 8 & $4-8$ \\
\hline Naphthacemycin $C_{1}(16)$ & $>8$ & $>8$ & $>8$ \\
\hline Naphthacemycin $C_{2}(\mathbf{1 7})$ & $>8$ & $>8$ & $>8$ \\
\hline Vancomycin & $1-2$ & 1 & 1 \\
\hline
\end{tabular}

linezolid-resistant MRSA. Moreover, they showed good inhibition against vancomycin-resistant Enterococcus faecalis and E. faecium. Acute toxicity of $\mathbf{8}$ and $\mathbf{9}$ against mice was not observed at $100 \mathrm{mg} \mathrm{kg}^{-1}$ (s.c.).

The naphthacemycin A series has a unique skeleton of 7-phenylnaphthacene-5,6,11(12H)-trione. Most structurally related compounds, tetarimycin A $(\mathbf{1 8} \text {, Figure } 3)^{8}$ and fasamycins $(\mathbf{1 9}, \mathbf{2 0})^{9}$, were recently reported by Brady and co-workers as antibacterial agents. The antibacterial activity mechanism was identified as inhibition of FabF, one of the enzymes involved in type II fatty acid biosynthesis. ${ }^{10}$ Therefore, biological properties of naphthacemycins might be related to FabF inhibition, though we have not tested whether they could show inhibitory activity against FabF and type II fatty acid biosynthesis or not yet. Tetracycline (21) produced by Streptomyces spp. also has a naphthacene skeleton, but it is much more saturated and has a kink between rings $\mathrm{A}$ and $\mathrm{B}$, which is believed to be involved in its binding to ribosomes. ${ }^{11}$ Chelocardin (22), produced by Nocardia sulphurea, has a much more planar skeleton. ${ }^{12}$ Its bactericidal activity is not caused by protein synthesis inhibition but is believed to be due to membrane disruption. ${ }^{13}$ Tetracenomycin C (23), produced by S. glaucescens, is an another type of naphthacene antibiotic. ${ }^{14,15}$ It binds to DNA and mainly inhibits the growth of actinobacteria. EA-371 $\alpha$ (24), produced by Streptomyces sp., was isolated as an inhibitor of the MexAB-OprM efflux pump, which is involved in intrinsic antibiotic resistance of Pseudomonas aeruginosa. ${ }^{16}$ Though its skeleton is 8 -oxobenzo $[a]$ naphthacene, it has a 1,3-dihydroxy-10,10-dimethylanthrone unit, similar to the naphthacemycins. Its desulfonated analog, benastatin A (25), is active against Gram-positive bacteria. ${ }^{17}$ Bischloroanthrabenzoxocinone (26), produced by Streptomyces sp., also has the same unit. ${ }^{18,19}$ It also inhibits bacterial type II fatty acid biosynthesis and shows antibacterial activity against Gram-positive bacteria. The currently unknown mode of action of naphthacemycins may be similar to that of one of the above compounds.
Table 4 Antibacterial activity of naphthacemycins $A_{8}(8)$ and $A_{9}(9)$ compared with vancomycin

\begin{tabular}{|c|c|c|c|}
\hline \multirow[b]{2}{*}{ Bacteria } & \multicolumn{3}{|c|}{$M I C\left(\mu g m l^{-1}\right)$} \\
\hline & 8 & 9 & Vancomycin \\
\hline Staphylococcus aureus FDA209P (MSSA) & 2 & 2 & 1 \\
\hline S. aureus Smith (MSSA) & 1 & 1 & 2 \\
\hline S. aureus ISP447 (MSSA) & 1 & 1 & 1 \\
\hline S. aureus ISP217 (MSSA) & 1 & 1 & 1 \\
\hline S. aureus 70 (MRSA) & 2 & 1 & 0.5 \\
\hline S. aureus KB 362 (MRSA) & 1 & 1 & 1 \\
\hline S. aureus KB 363 (MRSA) & 2 & 1 & 1 \\
\hline S. aureus Mu50 (MRSA) & 2 & 2 & 8 \\
\hline S. aureus Linezolid resistant-6 (MRSA) & 4 & 2 & 2 \\
\hline S. epidermidis & 1 & 1 & 1 \\
\hline Kocuria rhizophila ATCC9341 & 0.5 & 1 & 1 \\
\hline Enterococcus faecalis ATCC21212 & 0.5 & 2 & 4 \\
\hline E. faecalis NCTC12201 (VanA) & 0.5 & 2 & $>128$ \\
\hline E. faecium NCTC12203 (VanA) & 2 & 4 & $>128$ \\
\hline Escherichia coli NIHJ JC-2 & $>128$ & $>128$ & $>128$ \\
\hline Citrobactor freundii ATCC8090 & $>128$ & $>128$ & $>128$ \\
\hline Klebsiella pneumoniae NCTN9632 & $>128$ & $>128$ & $>128$ \\
\hline Proteus mirabilis IF03849 & $>128$ & $>128$ & $>128$ \\
\hline P. vulgaris $\mathrm{OX}-19$ & $>128$ & $>128$ & $>128$ \\
\hline Morganella morganii IID Kono & $>128$ & $>128$ & $>128$ \\
\hline Serratia marcescens IF012648 & $>128$ & $>128$ & $>128$ \\
\hline Enterobacter cloacae IF013535 & $>128$ & $>128$ & $>128$ \\
\hline E. aerogenes NCTC10006 & $>128$ & $>128$ & $>128$ \\
\hline Pseudomonas aeruginosa 46001 & $>128$ & $>128$ & $>128$ \\
\hline$P$. aeruginosa $\mathrm{E}-2$ & $>128$ & $>128$ & $>128$ \\
\hline Acinetobacter calcoaceticus IF02552 & $>128$ & $>128$ & $>128$ \\
\hline
\end{tabular}

\section{METHODS}

\section{Taxonomy of the producing organism}

The International Streptomyces Project media recommended by Shirling and Gottlieb $^{20}$ as well as media recommended by Waksman ${ }^{21}$ were used to investigate the cultural characteristics. Cultures were observed after incubation for 2 weeks at $28^{\circ} \mathrm{C}$. The morphological properties were observed using a scanning electron microscope JSM-5600 (JEOL, Akishima, Japan). Isomers of diaminopimelic acid in whole-cell hydrolysates were elucidated by TLC $^{22}$ and menaquinones were analyzed by HPLC. ${ }^{23}$

\section{Media}

The agar slant medium for the stock culture of the strain KB-3346-5 consisted of starch (Kanto Chemical Co., Tokyo, Japan) 1.0\%, NZ amine (Wako Pure Chemical Industries, Osaka, Japan) $0.3 \%$, yeast extract (Oriental Yeast Co., Tokyo, Japan) $0.1 \%$, meat extract (Kyokuto Pharmaceutical Industrial Co., Tokyo, Japan) $0.1 \%, \mathrm{CaCO}_{3} 0.3 \%$ and agar (Shimizu Shokuhin Kaisha, Shizuoka, Japan) $1.5 \%$, adjusted to $\mathrm{pH} 7.0$ before sterilization. The seed medium consisted of starch $2.4 \%$, glucose $0.1 \%$, peptone (Kyokuto Pharmaceutical Industrial Co.) $0.3 \%$, yeast extract $0.5 \%$, meat extract $0.3 \%$ and $\mathrm{CaCO}_{3}$ $0.4 \%$, adjusted to $\mathrm{pH} 7.0$ before sterilization. The production medium consisted of glucose $0.5 \%$, corn steep powder (Marcor Development Co., Carlstadt, NJ, USA) 0.5\%, oatmeal (Nippon Food Manufacturer, Sapporo, Japan) 1.0\%, Pharmamedia (Traders Protein, Lubbock, TX, USA) $1.0 \%, \mathrm{~K}_{2} \mathrm{HPO}_{4} 0.5 \%$, $\mathrm{MgSO}_{4} \cdot 7 \mathrm{H}_{2} \mathrm{O} \quad 0.5 \%, \quad \mathrm{FeSO}_{4} \cdot 7 \mathrm{H}_{2} \mathrm{O} \quad 0.0001 \%, \quad \mathrm{MnCl}_{2} \cdot 4 \mathrm{H}_{2} \mathrm{O} \quad 0.0001 \%$, $\mathrm{ZnSO}_{4} \cdot 7 \mathrm{H}_{2} \mathrm{O} 0.0001 \%$, $\mathrm{CuSO}_{4} \cdot 5 \mathrm{H}_{2} \mathrm{O} \quad 0.0001 \%$ and $\mathrm{CoCl}_{2} \cdot 6 \mathrm{H}_{2} \mathrm{O} 0.0001 \%$, adjusted to $\mathrm{pH} 7.0$ before sterilization.

\section{Isolation}

A mixture of the cultured broth (5l) and the same volume of acetone was shaken for $30 \mathrm{~min}$. Acetone in the solution was removed by evaporation and 
<smiles>Cc1cc(O)cc2c1C(=O)C1=C(C2=O)C(C)(C)c2cc(O)cc(O)c2C1=O</smiles>

Tetarimycin A (18)<smiles>[R]c1c(O)c(C)c2c(c1O)C(=O)c1c(c(O)c(-c3c(C)cc(O)cc3O)c3cc(O)ccc13)C2(C)C</smiles>

Fasamycin $A(19)$
Fasamycin $B(20)$

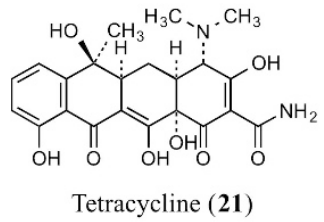<smiles>[R9]c1cc(O)c2c(c1)C(C)(C)c1cc3c(ccc4cc(CCCCC)c(C(=O)O)c(O)c43)c(O)c1C2=O</smiles>

Benastatin A (25) R=H<smiles>CC(=O)C1=C(O)C(N)C2Cc3c(c(C)c4ccc(C)c(O)c4c3O)C(=O)[C@@]2(C)C1=O</smiles>

Chelocardin (22)<smiles>COC(=O)c1c(OC)cc2cc3c(c(O)c2c1C)C(=O)[C@]1(O)C(=O)C=C(OC)[C@H](O)[C@@]1(O)C3=O</smiles>

Tetracenomycin C (23)

Figure 3 Structures of naphthacemycin-related antibiotics.

the remaining water solution was partitioned with 101 of ethyl acetate. The ethyl acetate extract $(6.73 \mathrm{~g})$ was applied to a silica gel column ( $220 \mathrm{~g}$ of silica gel $60(0.063-0.200 \mathrm{~mm})$, Merck KGaA, Darmstadt, Germany), washed with $\mathrm{CHCl}_{3}$ and eluted with $\mathrm{CHCl}_{3}-\mathrm{MeOH}$ (100:1, 100:2 and 100:10). Active fractions eluted with $\mathrm{CHCl}_{3}-\mathrm{MeOH}(100: 1)$ and $\mathrm{CHCl}_{3}-\mathrm{MeOH}$ (100:10) were concentrated to yield crude materials I $(4.37 \mathrm{~g})$ and II $(0.83 \mathrm{~g})$, respectively.

A total of $1.0 \mathrm{~g}$ of the crude material I was used for the further purification. It was applied to a silica gel column (30 g of silica gel $60(0.040-0.063 \mathrm{~mm})$, Merck KGaA) and eluted with $\mathrm{CHCl}_{3}-\mathrm{MeOH}$ (100:0, 100:1 and 100:2). Naphthacemycins were eluted at 100:0 to 100:2 ratio solutions to yield crude materials III $(472 \mathrm{mg})$ and IV $(69.2 \mathrm{mg})$. The crude material III was separated by ODS HPLC (column, Pegasil ODS, $\varphi 20 \times 250 \mathrm{~mm}$, Senshu Scientific Co., Tokyo, Japan; mobile phase, $60 \% \mathrm{CH}_{3} \mathrm{CN}$; flow rate, $8 \mathrm{ml} \mathrm{min}^{-1}$ ). Crude material V $(295 \mathrm{mg})$ and naphthacemycins $\mathrm{A}_{10}(\mathbf{1 0}, 14.7 \mathrm{mg}), \mathrm{A}_{11}(\mathbf{1 1}, 55.7 \mathrm{mg})$ and $C_{2}(17,9.2 \mathrm{mg})$ were eluted at $43,49,51$ and $55 \mathrm{~min}$, respectively. The crude material V was further purified by ODS HPLC (column, Pegasil ODS,

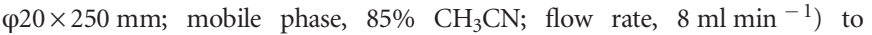
yield naphthacemycins $A_{8}(8,106 \mathrm{mg})$ and $A_{9}(9,175 \mathrm{mg})$ at the eluate of 23 and $27 \mathrm{~min}$, respectively. Crude material IV was purified by Pegasil ODS HPLC using $55 \% \mathrm{CH}_{3} \mathrm{CN}$ (flow rate, $8 \mathrm{ml} \mathrm{min}^{-1}$ ) to yield naphthacemycins $A_{5}(5,26.4 \mathrm{mg}), A_{6}(6,11.5 \mathrm{mg})$ and $A_{7}(7,14.3 \mathrm{mg})$ at the retention times of 25,36 and $38 \mathrm{~min}$, respectively.

The crude material II was applied to a silica gel column $(25 \mathrm{~g}$ of silica gel $60(0.040-0.063 \mathrm{~mm})$, Merck $\mathrm{KGaA})$ and eluted with $\mathrm{CHCl}_{3}-\mathrm{MeOH}$ (100:2 and 100:10). Naphthacemycins eluted at 100:2 and 100:10 ratios were collected to yield crude materials VI (170 mg) and VII (251 mg), respectively. The crude material VI was separated by Pegasil ODS HPLC using $75 \%$ $\mathrm{MeOH}$ (flow rate, $8 \mathrm{ml} \mathrm{min}^{-1}$ ), and naphthacemycins $\mathrm{A}_{2}\left(2,13.9 \mathrm{mg}\right.$ ), $\mathrm{B}_{3}$ $(14,10.0 \mathrm{mg})$ and $\mathrm{B}_{4}(15,30.5 \mathrm{mg})$ and crude materials VIII $(20.2 \mathrm{mg})$ and IX $(61.2 \mathrm{mg})$ were eluted at 17, 19,27, 22 and $36 \mathrm{~min}$, respectively. The crude material VIII was applied to Pegasil ODS HPLC using $55 \% \mathrm{CH}_{3} \mathrm{CN}$ (flow rate, $8 \mathrm{ml} \mathrm{min}^{-1}$ ), and the eluted peak of $18 \mathrm{~min}$ was collected to yield naphthacemycin $\mathrm{C}_{1}(\mathbf{1 6}, 14.2 \mathrm{mg})$. The crude material IX was further purified by Pegasil ODS HPLC using $55 \% \mathrm{CH}_{3} \mathrm{CN}$ (flow rate, $8 \mathrm{ml} \mathrm{min}^{-1}$ ) to yield naphthacemycins $\mathrm{A}_{3}(3,21.5 \mathrm{mg})$ and $\mathrm{A}_{4}(4,32.8 \mathrm{mg})$ at the eluate of 21 and $24 \mathrm{~min}$, respectively. The crude material VII was separated by Pegasil ODS HPLC using $50 \% \mathrm{CH}_{3} \mathrm{CN}$ (flow rate, $8 \mathrm{ml} \mathrm{min}^{-1}$ ), and crude material $\mathrm{X}(29.9 \mathrm{mg}$ ) and naphthacemycin $B_{2}(13,89.6 \mathrm{mg})$ were eluted at 12 and $19 \mathrm{~min}$, respectively. The crude material $\mathrm{X}$ was further purified by Pegasil ODS HPLC using $65 \%$ $\mathrm{MeOH}$ (flow rate, $7 \mathrm{ml} \mathrm{min}^{-1}$ ) to yield naphthacemycins $\mathrm{B}_{1}(\mathbf{1 0}, 10.0 \mathrm{mg}$ ) and $\mathrm{A}_{1}(1,14.2 \mathrm{mg})$ at the eluate of 36 and $44 \mathrm{~min}$, respectively.

\section{Assay of antibacterial activity}

Measurement of anti-MRSA activity of imipenem enhanced by naphthacemycins were carried out by the liquid microdilution method $^{24}$ using MRSA strain $\mathrm{K} 24$, as reported previously. ${ }^{4}$

A larger panel for sensitivity testing of clinically isolated MRSA (22 strains) and drug susceptible (MSSA) organisms (5 strains) were carried out by the agar dilution method ${ }^{25}$ in the presence of imipenem and/or naphthacemycins. An overnight culture of MRSA and MSSA strains was diluted with fresh medium to the appropriate bacterial density and spread onto a plate of Difco Mueller Hinton Agar (Becton, Dickinson and Company, Sparks, MD, USA) containing serial twofold dilutions of imipenem or naphthacemycins. To measure imipenem activity enhancement, 0.2 or $1 \mu \mathrm{g} \mathrm{ml}{ }^{-1}$ of naphthacemycins was added with imipenem. To measure naphthacemycins activity, naphthacemycins alone were added. The plates were incubated at $37^{\circ} \mathrm{C}$ for $20 \mathrm{~h} . \mathrm{MIC}_{50}$ was defined as the concentration at which $50 \%$ of the strains could not grow.

Antibacterial activity of naphthacemycins against a variety of bacteria were measured by the agar dilution method. ${ }^{25}$

\section{CONFLICT OF INTEREST}

The authors declare no conflict of interest.

\section{ACKNOWLEDGEMENTS}

This work was supported in part by a grant of the twenty-first century COE Program, Ministry of Education, Culture, Sports, Science and Technology, Japan.

1 Diep, B. A. \& Otto, M. The role of virulence determinants in community-associated MRSA pathogenesis. Trends Microbiol. 16, 361-369 (2008).

2 Iwatsuki, M. et al. Biverlactones A-D, new circumventors of arbekacin resistance in MRSA, produced by Penicillium sp. FKI-4429. Tetrahedron 67, 6644-6648 (2011). 
3 Fukumoto, A. et al. Cyslabdan, a new potentiator of imipenem activity against methicillin-resistant Staphylococcus aureus, produced by Streptomyces $\mathrm{sp}$ K04-0144. I. Taxonomy, fermentation, isolation and structural elucidation. J. Antibiot. 61, 1-6 (2008)

4 Fukumoto, A. et al. Cyslabdan, a new potentiator of imipenem activity against methicillinresistant Staphylococcus aureus, produced by Streptomyces sp. K04-0144. II. Biological activities. J. Antibiot. 61, 7-10 (2008).

5 Omura, S. et al. (Kitasato Institute, Japan; Kyowa Hakko Kirin Co., Ltd., Japan), KB-3346-5 substances, their fermentative manufacture, and antibacterial agents containing them. Jpn. Kokai Tokkyo Koho, JP2009046404A (2009).

6 Williams, S. T., Goodfellow, M. \& Alderson, G. in: Bergey's Manual of Systematic Bacteriology, Vol. 4 (eds Wiliams, S. T. et al.) 2452-2492 (Williams \& Wilkins, Baltimore, MD, USA, 1989).

7 Fukumoto, A. et al. Naphthacemycins, novel circumventors of $\beta$-lactam resistance in MRSA, produced by Streptomyces sp. KB-3346-5. II. structure elucidation. J. Antibiot. (doi:10.1038/ja.2017.29).

8 Kallifidas, D., Kang, H.-S. \& Brady, S. F. Tetarimycin A, an MRSA-active antibiotic identified through induced expression of environmental DNA gene clusters. J. Am. Chem. Soc. 134, 19552-19555 (2012).

9 Feng, Z., Kallifidas, D. \& Brady, S. F. Functional analysis of environmental DNA-derived type II polyketide synthases reveals structurally diverse secondary metabolites. Proc. Natl Acad. USA 108, 12629-12634 (2011).

10 Feng, Z., Chakraborty, D., Dewell, S. B., Reddy, B. V. B. \& Brady, S. F. Environmental DNA-encoded antibiotics fasamycins $A$ and $B$ inhibit FabF in type II fatty acid biosynthesis. J. Am. Chem. Soc. 134, 2981-2987 (2012).

11 Thaker, M., Spanogiannopoulos, P. \& Wright, G. D. The tetracycline resistome. Cell Mol. Life Sci. 67, 419-431 (2010).

12 Oliver, T. J., Prokop, J. F., Bower, R. R. \& Otto, R. H. Chelocardin, a new broadspectrum antibiotic. I. Discovery and biological properties. Antimicrob. Agents Chemother. 1962, 583-591 (1963).
13 Chopra, I. Tetracycline analogs whose primary target is not the bacterial ribosome. Antimicrob. Agents Chemother. 38, 637-640 (1994).

14 Weber, W., Zähner, H., Siebers, J., Schröder, K. \& Zeeck, A. Stoffwechselprodukte von Mikroorganismen. 175. Mitteilung. Tetracenomycin C. Arch. Microbiol. 121, 111-116 (1979).

15 Weber, W., Zähner, H., Siebers, J., Schröder, K. \& Zeeck, A. in: Actinomycetes. Zbl. Bakt. Suppl. 11 (eds Schaal, K. P. \& Pulverer, G.) 465-468 (Gustav Fischer Verlag, Stuttgart, 1981).

16 Lee, M. D. et al. Microbial fermentation-derived inhibitors of efflux-pump-mediated drug resistance. Farmaco 56, 81-85 (2001).

17 Aoyagi, T. et al. Benastatins A and B, new inhibitors of glutathione S-transferase, produced by Streptomyces sp. M1384-DF12. I. Taxonomy, production, isolation, physico-chemical properties and biological activities. J. Antibiot. 45, 1385-1390 (1992)

18 Kodali, S. et al. Determination of selectivity and efficacy of fatty acid synthesis inhibitors. J. Biol. Chem. 280, 1669-1677 (2005).

19 Herath, K. B. et al. Anthrabenzoxocinones from Streptomyces sp. as liver X receptor ligands and antibacterial agents. J. Nat. Prod. 68, 1437-1440 (2005).

20 Shiring, E. B. \& Gottlieb, D. Methods for characterization of Streptomyces species. Int J. Syst. Bacteriol. 16, 313-340 (1966).

21 Waksman S. A. (ed.) In The Actinomycetes Vol.2, (Williams \& Wilkins, Baltimore, 1961).

22 Hasegawa, T., Takizawa, M. \& Tanida, S. A rapid analysis for chemical grouping of aerobic actinomycetes. J. Gen. Appl. Microbiol. 29, 319-322 (1982).

23 Collins, M. D., Pirouz, T., Goodfellow, M. \& Minnikin, D. E. Distribution of menaquinones in actinomycetes and corynebacteria. J. Gen. Microbiol. 100, 221-230 (1977).

24 Japanese Society of Chemotherapy. Report of the committee for Japanese standards for antimicrobial susceptibility testing for bacteria. Chemotherapy 38, 102-105 (1990).

25 Nagayama, A. et al. Final report from the Committee on Antimicrobial Susceptibility Testing, Japanese Society of Chemotherapy, on the agar dilution method (2007). J. Infect. Chemother. 14, 383-392 (2008). 